\title{
The Effect of Level of Education, Accounting Knowledge, and Utilization Of Information Technology Toward Quality The Quality of MSME's Financial Reports
}

\author{
Sri Hanifah ${ }^{1}$, Siti Sarpingah ${ }^{2}$, Yananto Mihadi Putra ${ }^{3}$ \\ \{ srihanifah28@gmail.com ${ }^{1}$, siti.sarpingah@ mercubuana.ac.id ${ }^{2}$, yananto.mihadi@mercubuana.ac.id ${ }^{3}$ \} \\ Universitas Mercu Buana, Jakarta ${ }^{1}$, Universitas Mercu Buana, Jakarta², Universitas Mercu Buana, \\ Jakarta $^{3}$
}

\begin{abstract}
The aim of this research is to analyze the effect of educational levels, accounting knowledge, and technology of information toward quality of financial statement. There are 194 SMEs in Kalidereswhich becomes populations of this research and by using purposive sampling method, there are 85 respondents selected. The research method used is quantitative research method. Program used in analyzing the data using SmartPLS 3.0 and for descriptive using SPSS 22. The results of this research show that the educational levels does not effects the quality of financial statement while accounting knowledge, and technology of information are positifly significant influences the quality of financial statement.
\end{abstract}

Keywords: Quality of Financial Statement, Educational Levels, Accounting Knowledge, Technology of Information.

\section{Pendahuluan}

Pertumbuhan perekonomian di Indonesia masih banyak mengalami kendala. Berbagai macam masalah terjadi di negara ini khususnya bidang ekonomi. Salah satu masalah yang menjadi pukulan telak bagi bangsa Indonesia yakni krisis ekonomi pada tahun 1997-1998 (1). Pada Forum Ekonomi Islam Dunia (World Islamic Economic Forum / WIFE) ke-12 Mulyani sebagai menteri keuangan menyatakan bahwa UMKM dapat menjadi penahan saat guncangan ekonomi dan menyerap tenaga kerja dengan menitikberatkan pada peranan UMKM dalam mendorong pertumbuhan ekonomi dan UMKM telah berperan serta dalam penciptaan lapangan kerja dan mampu menyelamatkan sebuah negara dari ketidakstabilan ekonomi (2) [15].

Pradiasmo sebagai Ketua Dewan Pengurus Nasional Ikatan Akuntan Indonesia menyatakan bahwa Usaha Mikro, Kecil, dan Menengah (UMKM) terbukti mendorong dan meningkatkan pertumbuhan ekonomi nasional secara berkesinambungan. Kontribusi besar UMKM meliputi penciptaan lapangan kerja, penyerapan tenaga kerja, dan terutama menjadi penahan saat terjadinya guncangan krisis ekonomi. Melihat peran penting tersebut, dibutuhkan dukungan dari seluruh pihak untuk mengembangkan dan mewujudkan UMKM yang maju, mandiri, dan modern, termasuk memiliki akses pendanaan yang semakin luas ke sektor perbankan (3). 
Berdasarkan laporan Kementrian Usaha Kecil Menengah jumlah UMKM di Indonesia pada tahun 2015 mencapai 99,99\% dari total 59.267.759-unit usaha yang tersebar di seluruh wilayah Indonesia. Besarnya jumlah tersebut mencerminkan besarnya potensi yang dapat dikembangkan dan ditingkatkan oleh UMKM untuk dapat lebih berkontribusi bagi Indonesia.

Tabel 1. Perkembangan Unit Usaha Tahun 2013-2017 (Unit) Sumber : depkop.go.id (data diolah), (2018)

\begin{tabular}{|l|r|r|r|r|r|}
\hline \multicolumn{1}{|c|}{ Indikator } & \multicolumn{1}{c|}{$\mathbf{2 0 1 3}$} & \multicolumn{1}{c|}{$\mathbf{2 0 1 4}$} & \multicolumn{1}{c|}{$\mathbf{2 0 1 5}$} & \multicolumn{1}{c|}{$\mathbf{2 0 1 6}$} & \multicolumn{1}{c|}{$\mathbf{2 0 1 7}$} \\
\hline Us aha Mikro & 55.856 .176 & 57.189 .393 & 58.521 .987 & 60.863 .578 & 62.106 .900 \\
\hline Us aha Kecil & 629.418 & 654.222 & 681.522 & 731.047 & 757.090 \\
\hline $\begin{array}{l}\text { Us aha } \\
\text { Menengah }\end{array}$ & 48.997 & 52.106 & 59.263 & 56.551 & 58.627 \\
\hline Total UMKM & $\mathbf{5 6 . 5 3 4 . 5 9 2}$ & $\mathbf{5 7 . 8 9 5 . 7 2 1}$ & $\mathbf{5 9 . 2 6 2 . 7 7 2}$ & $\mathbf{6 1 . 6 5 1 . 1 7 7}$ & $\mathbf{6 2 . 9 2 2 . 6 1 7}$ \\
\hline Us aha Bes ar & 4.968 & 5.066 & 4.987 & 5.370 & 5.460 \\
\hline Unit Usaha & $\mathbf{5 6 . 5 3 9 . 5 6 0}$ & $\mathbf{5 7 . 9 0 0 . 7 8 7}$ & $\mathbf{5 9 . 2 6 7 . 7 5 9}$ & $\mathbf{6 1 . 6 5 6 . 5 4 7}$ & $\mathbf{6 2 . 9 2 8 . 0 7 7}$ \\
\hline
\end{tabular}

Tabel 2. Perkembangan Komposisi PDB Menurut Kelompok Usaha Tahun 2013-2017 Atas Dasar Harga Konstan 2000 (Milyar Rupiah)

Sumber: depkop.go.id (data diolah), (2018)

\begin{tabular}{|c|r|r|r|r|r|}
\hline Indikator & \multicolumn{1}{c|}{$\mathbf{2 0 1 3}$} & \multicolumn{1}{c|}{$\mathbf{2 0 1 4}$} & \multicolumn{1}{c|}{$\mathbf{2 0 1 5}$} & \multicolumn{1}{c|}{$\mathbf{2 0 1 6}$} & \multicolumn{1}{c|}{$\mathbf{2 0 1 7}$} \\
\hline Usaha Mikro & 790.826 & 807.805 & 848.985 & 2.736 .614 & 2.856 .608 \\
\hline Usaha Kecil & 294.261 & 342.579 & 395.426 & 1.123 .132 & 1.191 .871 \\
\hline Usaha Menengah & 366.374 & 386.535 & 411.019 & 1.311 .318 & 1.376 .936 \\
\hline Total UMKM & $\mathbf{1 . 4 5 1 . 4 6 1}$ & $\mathbf{1 . 5 3 6 . 9 1 9}$ & $\mathbf{1 . 6 5 5 . 4 3 0}$ & $\mathbf{5 . 1 7 1 . 0 6 4}$ & $\mathbf{5 . 4 2 5 . 4 1 5}$ \\
\hline Usaha Besar & 1.073 .660 & 1.133 .396 & 1.211 .008 & 3874676 & 4.078 .734 \\
\hline Unit Usaha & $\mathbf{2 . 5 2 5 . 1 2 1}$ & $\mathbf{2 . 6 7 0 . 3 1 5}$ & $\mathbf{2 . 8 6 6 . 4 3 8}$ & $\mathbf{9 . 0 4 5 . 7 4 0}$ & $\mathbf{9 . 5 0 4 . 1 4 9}$ \\
\hline
\end{tabular}

Berdasarkan tabel 1 dan tabel 2 dapat disimpulkan bahwa jumlah UMKM di Indonesia telah mampu mendominasi unit usaha. Dalam usaha pemberdayaan sektor UMKM yang merupakan salah satu pondasi perekonomian yang kuat ternyata masih memiliki beberapa masalah dalam perkembangannya, seperti (1) akses ke sumber finansial, baik ke lembaga keuangan baik bank maupun bukan bank, (2) kapasitas modal manusia pelaku UMKM masih tergolong rendah, (3) kemampuan inovasi produk, (4) kapasitas pemasaran dan jaringan usaha terbatas, (5) kemampuan teknologi produksi yang masih rendah, dan (6) lemahnya kemampuan manajerial dan sumber daya manusia mengakibatkan pengusaha kecil tidak mampu menjalankan usahanya dengan baik (Fauzi dkk, 2016). Hasan Supriadi sebagai pimpinan sentra kredit kecil BNK Surabaya menyatakan bahwa pelaku UMKM yang paham dan memiliki laporan keuangan sangat sedikit bahkan tidak sampai 10\%. (www.okezone.com, 2017) (4).

UMKM juga merupakan awal pertumbuhan perusahaan besar. Hampir semua bisnis besar dimulai dari usaha kecil. Namun sayangnya, banyak perusahaan kecil tidak memiliki sistem akuntansi keuangan yang baik. Mereka terlalu fokus pada bagaimana membuat produk yang unik, sedangkan akuntansi dan keuangan sistem sering dianggap sebagai pilihan kedua, 
bukan sebagai pilihan prioritas. Selain itu, pelaku UMKM juga menganggap bahwa pemberian catatan akuntansi akan membuang-buang waktu dan biaya. Mereka merasa terganggu dengan catatan keuangan dan berpikir bahwa hal yang paling penting adalah untuk mendapatkan keuntungan maksimum (5).

Masalah yang sering dihadapi oleh para pelaku UKM antara lain mengenai pendanaan, pemasaran produk, teknologi, pengelolaan keuangan, kualitas sumber daya manusia (6). Salah satu masalah yang seringkali terabaikan oleh para pelaku bisnis UMKM yaitu mengenai pengelolaan keuangan. Menurut Putra (2018), mayoritas pengelola UMKM belum menerapkan pengelolaan keuangan menurut standar yang berlaku (6). Dampak dari diabaikannya pengelolaan keuangan mungkin tidak terlihat secara jelas, namun tanpa metode akuntansi yang efektif, usaha yang memiliki prospek untuk berhasil dapat menjadi bangkrut. Akuntansi merupakan kunci dari indikator kinerja usaha. Informasi yang disediakan oleh catatan-catatan akuntansi berguna bagi pengambilan keputusan sehingga dapat meningkatkan pengelolaan perusahaan. Informasi-informasi tersebut memungkinkan para pelaku UMKM dapat mengidentifikasi dan memprediksi area-area permasalahan yang mungkin timbul, kemudian mengambil tindakan koreksi tepat waktu. Tanpa informasi akuntansi, masalahmasalah yang sedianya dapat dihindari atau dipecahkan justru menjadi penyebab kebangkrutan usaha tersebut. Untuk itu, penting sekali bagi pengusaha untuk dapat membaca dan menafsirkan informasi akuntansi. Paling tidak, setiap pengusaha dapat menghitung untung ruginya, akan tetapi yang paling penting untuk dapat memahami makna untung atau rugi bagi usahanya. (Hutagol, 2012) (7).

Pratama sebagai Director of Commerce Mars menyatakan bahwa salah satu kelemahan UKM di Indonesia yaitu masih digunakannya cara-cara tradisional dan manual dalam kegiatan usahanya. Masalah yang umum dihadapi oleh pelaku UKM adalah kurangnya akses atas informasi, modal, keahlian dan dukungan institusional (www.kominfo.go.id, 2012) (8). Didukung juga dengan pernyataan Tanjung (2017) dan Putra (2018) yang menyatakan bahwa, umumnya UMKM tidak memiliki catatan (laporan) keuangan sehingga keuntungan dalam usaha sering kali tidak diperhitungkan (9),(6). Jika usaha sedang untung, keuntungan tersebut sering kali habis terkonsumsi, bahkan tidak jarang pendapatan yang diperoleh semuanya dianggap sebagai keuntungan, padahal diantara keuntungan yang dimaksud terdapat modal yang terpakai untuk konsumsi. Jika ini terjadi, kegiatan perusahaan akan terganggu dan tidak jarang volume kegiatan usaha akhirnya berkurang atau menurun yang nantinya dapat berdampak pada terhentinya kegiatan perusahaan.

Pentingnya penyusunan laporan keuangan bagi UMKM dapat sebagai pengendalian aset, kewajiban, dan modal, serta perencanaan pendapatan dan efisiensi biaya-biaya yang terjadi yang pada akhirnya sebagai alat untuk pengambilan keputusan perusahaan. Untuk memulai menerapkan pencatatan akuntansi, para pengelola usaha harus bisa memisahkan kepentingan keuangan usaha dengan pribadi/pemilik (www.kebumenkab.go.id, 2015) (10).

Saparini sebagai pengamat ekonomi menyatakan bahwa sebagian besar Sumber Daya Manusia (SDM) disektor UMKM masih rendah, karena di Indonesia 51\% tenaga kerja UMKM adalah berpendidikan Sekolah Dasar (SD). Kunci utama untuk meningkatkan kualitas UMKM harus dimulai dari sisi SDM yang terus ditingkatkan kualitas baik melalui pelatihanpelatihan atau perekrutan pekerja yang selektif (www.liputan6.com, 2014) (11).

Zabadi sebagai Direktur Utama Lembaga Layanan Pemasaran Koperasi dan Usaha Kecil Menengah menyatakan bahwa, usaha mengembangkan UKM di Indonesia bukan tanpa halangan. Salah satu kendala yang dialami pemerintah saat ini adalah kondisi SDM pelaku UKM yang masih belum merata. Dari sisi SDM masih kalah. Pelaku UKM basic pendidikannya dari data BPS hanya SD dan SMP, yakni 60-70 \% dari total UKM. Dengan 
basic yang masih rendah, kemampuan beradaptasi dengan perubahan menjadi lebih sulit. Karena saat ini masyarakat dituntut harus cepat beradaptasi (ekonomi.bisnis.com, 2017) (12).

Balai Penyedia dan Pengelola Pembiayaan Telekomunikasi dan Informatika (BP3TI) melakukan penelitian untuk menganalisis penggunaan teknologi informasi pada pelaku usaha mikro (ultra mikro), dalam penelitian tersebut, ditemukan rendahnya adopsi teknologi informasi pada para pelaku usaha ultra mikro. Selain itu, ditemukan pula bahwa masih rendahnya kesadaran akan manfaat dari aplikasi IT UKM. Oleh karena itu, diperlukan beberapa program untuk meningkatkan kesadaran akan manfaat IT (www.feb.ui.ac.id, 2017) (13).

Penelitian terdahulu yang dilakukan oleh Hadi (2015) (14), Lestari \& Priyadi (2017) (15), Devi d.k.k (2017) (16) mengungkapkan bahwa tingkat pendidikan berpengaruh secara positif terhadap kualitas laporan keuangan hal ini bertolak belakang dengan penelitan yang dilakukan oleh Mulyani (2014) (17) dan Wungow d.k.k (2016) (18) menyatakan bahwa jenjang pendidikan tidak berpengaruh secara positif terhadap kualitas laporan keuangan. Menurut penelitian Baihaqi (2016), Mahlil \& Yahya (2017), Lestari \& Priyadi (2017) menyatakan bahwa pengetahuan akuntansi berpengaruh positif terhadap kualitas keuangan (1),(19),(15). Penelitian yang dilakukan oleh Langenre (2017), Nadir \& Hasyim (2017) keduanya mengungkapkan bahwa pemanfaatan teknologi informasi berpengaruh positif terhadap kualitas laporan keuangan (20),(21), didukung dengan penelitian yang dilakukan oleh Chodijah \& Hidayah (2018) menyatakan bahwa pemanfaatan teknologi informasi berpengaruh positif dan signifikan terhadap kualitas laporan keuangan (22).

Dari uraian di atas dapat disimpulkan bahwa praktek akuntansi, khususnya akuntansi keuangan pada UMKM di Indonesia masih rendah dan memiliki banyak kelemahan. Kelemahan itu, antara lain bisa disebabkan karena rendahnya tingkat pendidikan SDM, kurangnya pemahaman terhadap pengetahuan akuntansi serta belum memanfaatkan teknologi informasi.

\section{Kajian Pustaka}

Teori stewardship adalah teori yang dicetuskan oleh Donaldson dan Davis (1991) (23), teori ini menjelaskan keadaan dimana manajer (steward) mengesampingkan kepentingan pribadinya untuk mencapai tujuan organisasi dan bertindak sesuai dengan keinginan pemilik (principal). Implikasi dari Teori Stewardship dengan penelitian ini adalah dapat menjelaskan untuk mencapai tujuan dari laporan keuangan yaitu menyediakan informasi posisi keuangan dan kinerja suatu entitas yang bermanfaat bagi sejumlah besar pengguna dalam pengambilan keputusan ekonomik oleh siapapun yang tidak dalam posisi dapat meminta laporan keuangan khusus untuk memenuhi kebutuhan informasi tersebut. Pengguna tersebut meliputi penyedia sumber daya bagi entitas, seperti kreditor maupun investor. Dalam memenuhi tujuannya, laporan keuangan juga menunjukkan pertanggung jawaban manajemen atas sumber daya yang dipercayakan kepadanya.

Dalam Undang-Undang Nomor 20 Tahun 2008 (24) Usaha mikro adalah usaha produktif milik perorangan dan/atau badan usaha perorangan yang memenuhi kriteria usaha mikro. Usaha kecil adalah usaha ekonomi produktif yang berdiri sendiri, dilakukan oleh perorangan atau badan usaha yang bukan merupakan anak perusahaan atau bukan cabang perusahaan yang dimiliki, dikuasai, atau menjadi bagian langsung maupun tidak langsung dari usaha menengah atau usaha besar. Usaha menengah adalah usaha ekonomi produktif yang berdiri sendiri, 
dilakukan oleh perorangan atau badan usaha yang bukan merupakan anak perusahaan atau cabang perusahaan yang dimiliki, dikuasai, atau menjadi bagian baik langsung maupun tidak langsung dari usaha kecil atau usaha besar dengan jumlah kekayaan bersih atau hasil penjualan tahunan sebagaimana diatur dalam UU.

Dalam SAK EMKM tujuan laporan keuangan adalah untuk menyediakan informasi posisi keuangan dan kinerja suatu entitas yang bermanfaat bagi sejumlah besar pengguna dalam pengambilan keputusan ekonomik oleh siapapun yang tidak dalam posisi dapat meminta laporan keuangan khusus untuk memenuhi kebutuhan informasi tersebut. Pengguna tersebut meliputi penyedia sumber daya bagi entitas, seperti kreditor maupun investor. Dalam memenuhi tujuannya, laporan keuangan juga menunjukkan pertanggungjawaban manajemen atas sumber daya yang dipercayakan kepadanya.

Yadiati \& Mubarok (2017: 32) mendefinisikan kualitas laporan keuangan merupakan kegiatan melaporkan informasi keuangan guna memenuhi kebutuhan pengguna (user's need) sekaligus memberikan perlindungan terhadap pemilik (investor's protection) dengan mendasarkan pada karakteristik kualitatif informasi keuangan dan pengungkapan secara penuh dan wajar (25).

Undang-Undang Sistem Pendidikan Nasional No. 20 Tahun 2003 (26) menjelaskan bahwa indikator tingkat pendidikan terdiri dari jenjang pendidikan dan kesesuaian jurusan. Jenjang pendidikan adalah tahapan pendidikan yang ditetapkan berdasarkan tingkat perkembangan peserta didik, tujuan yang akan dicapai, dan kemampuan yang dikembangkan yang terdiri dari pendidikan dasar, pendidikan menengah, dan pendidikan tinggi. Baihaqi (2016) Pengetahuan Akuntansi adalah segala sesuatu yang diketahui oleh pelaku usaha dengan penangkapan kelima inderanya berkenaan dengan ilmu akuntansi. Dalam penelitian Baihaqi pengetahuan akuntansi dapat diukur dengan Pengetahuan deklaratif dan Pengetahuan Prosedural (1).

Menurut Undang-Undang Nomor 11 Tahun 2008 (27) tentang Informasi dan Transaksi Elektronik pemanfaatan teknologi informasi berperan penting dalam perdagangan dan pertumbuhan perekonomian nasional untuk mewujudkan kesejahteraan masyarakat. Sistem dan teknologi informasi sangat berperan dalam bidang akuntansi untuk menyediakan informasi bagi pengambil keputusan, sehingga apabila sistem dan teknologi informasi baik akan dapat meningkatkan kinerja dengan organisasi dan sekaligus mampu mencegah dan mendeteksi kesalahan dalam aktivitas operasi perusahaan/organisasi. Dengan demikian adanya pemanfaatan teknologi informasi maka perusahaan /organisasi akan berjalan dengan lancar (22).

\section{Model penelitian, Hipotesis, dan Metodologi penelitian}




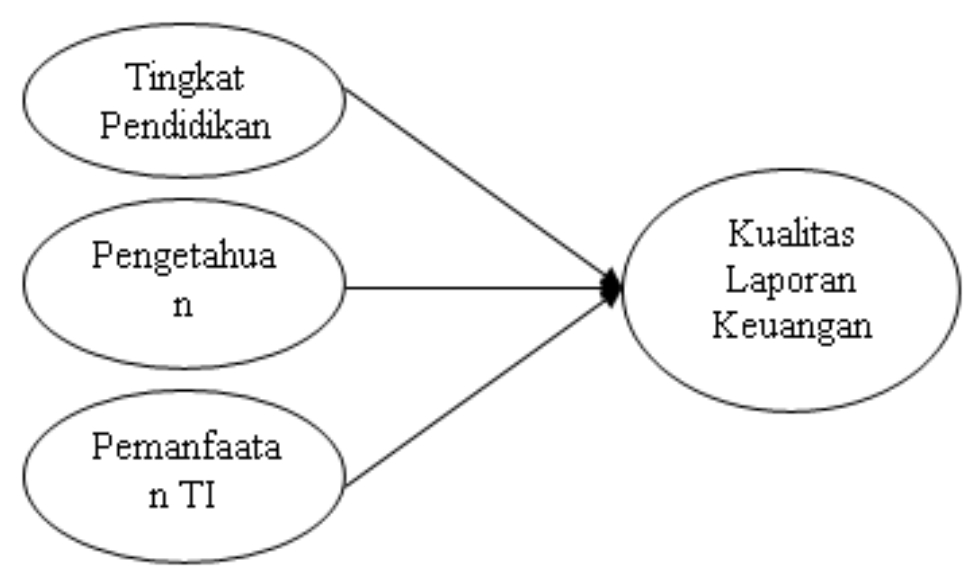

Gambar. 1. Model Konseptual

Berdasarkan latar belakang, rumusan, serta tujuan yang sudah diuraikan di atas, maka hipotesis di dalam penelitian ini adalah :

H1 : Tingkat pendidikan berpengaruh positif terhadap kualitas laporan keuangan.

$\mathrm{H} 2$ : Pengetahuan akuntansi berpengaruh positif terhadap kualitas laporan keuangan.

H3 : Pemanfaatan teknologi informasi berpengaruh positif terhadap kualitas laporan keuangan.

Penelitan ini difokuskan pada pemilik Usaha Mikro, Kecil, dan Menengah (UMKM) di wilayah kecamatan Kalideres, Jakarta Barat. Adapun waktu penelitian dilaksanakan pada tahun 2018 dengan mengumpulkan data menggunakan kuesioner. Populasi dalam penelitian ini adalah pelaku usaha mikro, kecil dan menengah. Penelitian ini dilakukan di wilayah kecamatan Kalideres, Jakarta Barat yang menurut data.jakarta.go.id memiliki 194 pemilik UMKM, sehingga populasinya sebesar 194. Sampel pada penelitian ini adalah 85 UMKM yang sudah memiliki sertifikat Izin Usaha Mikro Kecil (IUMK). Skala pengukuran dalam penelitian ini menggunakan skala likert dan skala nominal, masing-masing variabel diukur dengan model skala Likert lima poin, yaitu (1) Sangat Tidak Setuju, (2) Tidak Setuju, (3) Netral, (4) Setuju, dan (5) Sangat Setuju.Metode analisis data pada penelitian ini mengguanakan aplikasi SmartPLS 3.0 dan untuk analisa deskriptif menggunakan SPSS 22.

\section{Hasil dan Pembahasan}

\subsection{Uji Statistik Deskriptif}

Berdasarkan uji statistik deskriptif seluruh variabel menunjukkan bahwa merupakan data yang baik karena standar deviasi nya lebih kecil dari nilai mean. Standar deviasi lebih rendah dari nilai rata-rata hitung menunjukkan bahwa penyimpangan data dari sampel pada seluruh variabel relatif kecil sehingga nilai rata-rata hitung tersebut sudah dapat menggambarkan keadaan yang sebenarnya.

\section{2 . Uji Distribusi Frekuensi Penelitian}

Berdasarkan uji distribusi frekuensi data secara keseluruhan pada variabel tingkat pendidikan dapat disimpulkan bahwa responden pada penelitian ini memiliki latar belakang 
yang cukup sesuai dengan pekerjaan yang dilakukan sekarang. Variabel kedua yaitu pengetahuan akuntansi secara keseluruhan, hasil responden terhadap pengetahuan akuntansi memiliki respon yang baik dengan nilai frekuensi terbesar pada skala 4 sebesar 58,35\%. Artinya, responden setuju bahwa pengetahuan akuntansi baik pengetahuan prosedural dan pengetahuan deklaratif dapat mempengaruhi dari kualitas laporan keuangan. Variabel ketiga yaitu pemanfaatan teknologi informasi Secara keseluruhan, hasil responden terhadap pemanfaatan teknologi informasi memiliki respon yang baik dengan nilai frekuensi terbesar pada skala 4 sebesar 51,37\%. Artinya, responden setuju bahwa pemanfaatan teknologi informasi dengan dimensi tepat waktu dan akurat dapat mempengaruhi dari kualitas laporan keuangan. Variabel selanjutnya secara keseluruhan, hasil responden terhadap kualitas laporan keuangan memiliki respon yang baik dengan nilai frekuensi terbesar pada skala 4 sebesar $56,71 \%$.

\section{3 .. Uji Convergent Validity}

Berdasarkan hasil uji convergent validity, factor loading untuk second order dan first order sudah memenuhi syarat untuk uji convergent validity yaitu nilai indikatornya > 0.6 sehingga indikator tersebut sudah dikatakan valid dan untuk uji composite reliability seluruh variabel dan dimensi sudah memenuhi persyaratan yaitu memiliki nilai di atas 0,7 . Maka dari keempat variabel tersebut dapat disimpulkan semuanya memenuhi persyaratan validitas dan reliabilitas.

\section{4 .. Uji Inner Model}

Berdasarkan uji Inner model didapatkan hasil nilai R-Square sebesar 0,658. Hal ini berarti 65,8\% Kualitas Laporan Keuangan UMKM dipengaruhi oleh Tingkat Pendidikan, Pengetahuan Akuntansi, dan Pemanfaatan TI, sedangkan 34,2\% dijelaskan oleh sebab lainnya.

\section{5 . . Uji Dimensi Penelitian}

Berdasarkan uji dimensi penelitian, menunjukkan bahwa seluruh dimensi dalam variabel penelitian signifikan dalam membentuk konstruknya, dimana pengetahuan akuntansi dibentuk oleh dimensi pengetahuan deklaratif, dan pengetahuan prosedural. Konstruk pemanfaatan teknologi informasi dibentuk oleh dimensi tepat waktu, dan akurat. Konstruk kualitas laporan keuangan dibentuk oleh dimensi relevan, andal, dapat dibandingkan, dan dapat dipahami.

Dimensi yang paling besar kontribusinya dalam membentuk pengetahuan akuntansi adalah pengetahuan deklaratif karena ketika pelaku UMKM telah mengetahui pos-pos serta tata cara penjurnalan maka hasil laporan keuangan akan berkualitas karena di bukukan secara benar. Pada variabel pemanfaatanteknologi informasi dimensi yang memberikan kontribusiterbesar adalah akurat yang artinya pelaku UMKM tidak melakukan pembukuan secara tepat waktu (real time) tetapi menyetujui bahwa dengan melakukan pembukuan secara akurat (tepat) maka kualitas laporan keuangan akan lebih berkualitas. Dimensi yang paling besar kontribusinya dalam membentuk kualitas laporan keuangan adalah andal (Representasi Tepat) yang artinya ketika pembukuan di representasikan secara tepat maka kualitas laporan keuangan akan lebih berkualitas karena bebas dari kesalahan pencatatan.

\section{6 .. Uji Part Coeffisients (Uji Hipotesis)}


Berdasarkan uji Part Coefficients koefisien parameter jalur yang diperoleh dari pengaruh variabel tingkat pendidikan terhadap kualitas laporan keuangan adalah sebesar 0,029 dengan nilai Tstatistik $0,358<1,98$ pada taraf signifikansi $\alpha=0,05(5 \%)$ yang menyatakan bahwa tidak terdapat pengaruh antara tingkat pendidikan terhadap kualitas laporan keuangan karena nilai Tstatistik < 1,98. Hasil penelitian ini menolak hipotesis yang pertama, dimana terdapat pengaruh positif antara tingkat pendidikan terhadap kualitas laporan keuangan.

Koefisien parameter jalur yang diperoleh dari pengaruh variabel pengetahuan akuntansi terhadap kualitas laporan keuangan adalah sebesar 0,365 dengan nilai Tstatistik 5,963> 1,98 pada taraf signifikansi $\alpha=0,05(5 \%)$ yang menyatakan bahwa terdapat pengaruh positif antara pengetahuan akuntansi terhadap kualitas laporan keuangan dan signifikan. Pengaruh pengetahuan akuntansi mempunyai nilai koefisien regresi sebesar 0,365 artinya ketika pengetahuan akuntansi meningkat (bertambah 1) maka kualitas laporan keuangan akan naik sebesar 0,365. Begitu juga sebaliknya, Jika pengetahuan akuntansi menurun (berkurang 1) maka kualitas laporan keuangan pun akan menurun. Hasil penelitian ini mendukung hipotesis yang kedua, dimana terdapat pengaruh positif antara pengetahuan akuntansi terhadap kualitas laporan keuangan.

Koefisien parameter jalur yang diperoleh dari pengaruh variabel pemanfaatan teknologi informasi terhadap kualitas laporan keuangan adalah sebesar 0,559 dengan nilai Tstatistik $9,083>1.98$ pada taraf signifikansi $\alpha=0,05(5 \%)$ yang menyatakan bahwa terdapat pengaruh positif antara pemanfaatan teknologi informasi terhadap kualitas laporan keuangan dan signifikan. Pengaruh pemanfaatan teknologi informasi memiliki koefisien regresi sebesar 0,559 artinya ketika pemanfaatan teknologi informasi meningkat (bertambah 1) maka kualiatas laporan keuangan akan naik sebesar 0,559. Begitu juga sebaliknya, Jika pemanfaatan teknologi informasi menurun (berkurang 1) maka kualitas laporan keuangan pun akan menurun. Hasil penelitian ini mendukung hipotesis yang ketiga, dimana terdapat pengaruh positif antara pemanfaatan teknologi informasi terhadap kualitas laporan keuangan.

\section{Kesimpulan}

Dari hasil dan analisis statistic dalam penilitian ini, maka diambil kesimpulan antara lain sebagai berikut :

1. Tingkat pendidikan $\left(\mathrm{X}_{1}\right)$ tidak berpengaruh terhadap kualitas laporan keuangan. Hal ini menggambarkan bahwa tidak semua pelaku UMKM di Kecamatan Kalideres memiliki tingkat pendidikan yang tinggi serta mendapatkan ilmu pengetahuan akuntansi di pendidikan formal. Dikarenakan mayoritas dari responden hanya berpendidikan SD-SMA tetapi dengan mengikuti pelatihan, sosialiasasi serta dengan memanfaatkan teknologi yang ada, pelaku UMKM tetap dapat melakukan pembukuan dengan baik.

2. Pengetahuan akuntansi berpengaruh positif dan signifikan terhadap kualitas laporan keuangan. Hal ini menggambarkan bahwa semakin tinggi pengetahuan akuntansi pelaku UMKM maka laporan keuangan akan semakin berkualitas.

3. Pemanfaatan Teknologi Informasi berpengaruh positif dan signifikan terhadap kualitas laporan keuangan. Arah positif menunjukkan bahwa semakin tinggi pemanfaatan teknologi informasi digunakan maka akan mengurangi tingkat eror dalam pembuatan laporan keuangan sehingga kualitas laporan keuangan akan meningkat. 


\section{References}

1. Baihaqi WT. Pengaruh Persepsi Atas Tujuan Laporan Keuangan Dan Pengetahuan Akuntansi Terhadap Kualitas Laporan Keuangan UMKM. J Profita Kaji Ilmu Akunt. 2017;5(6).

2. Mulyani S. UMKM Penyelamat Saat Krisis. Retrieved Maret 2018 [Internet]. 2016. Available from: https://www.liputan6.com

3. Indonesia. IA. Standar Akuntansi Keuangan Entitas Mikro Kecil dan Menengah (2 ed.). Jakarta: Ikatan Akuntan Indonesia. 2018.

4. Supriyadi H. Masih Banyak Pelaku UMKM Buta Laporan Keuangan [Internet]. Retrieved November 2018. 2017. Available from:

https://www.okezone.com/topic/383/umkm

5. Putri AHK. PENGARUH FAKTOR LATAR BELAKANG PENDIDIKAN TERHADAP KUALITAS LAPORAN KEUANGAN MELALUI PENEGTAHUAN AKUNTANSI SEBAGAI VARIABEL INTERVENING. Ihtiyath J Manaj Keuang Syariah. 2017;1(2).

6. Putra YM. Pemetaan Penerapan Standar Akuntansi Keuangan EMKM Pada UMKM di Kota Tangerang Selatan. Profita. 2018;11(2):201-17.

7. Hutagaol RM. Penerapan Akuntansi Pada Usaha Kecil Menengah. J Ilm Mhs Akunt. 2012;1(2).

8. Pratama S. Pengeluaran UKM Untuk TI Maksimal Rp 830.000 [Internet]. Retrieved Maret 2018. 2012. Available from: https://kominfo.go.id

9. Tanjung MA. Koperasi dan UMKM sebagai fondasi perekonomian Indonesia. Penerbit Erlangga. 2017.

10. Supriono. Pelaku UKM Dituntut Paham Akuntansi [Internet]. Retrieved Maret 2018. 2015. Available from: http://www.kebumenkab.go.id

11. Praditya II. Kualitas SDM rendah diklaim jadi faktor sulit mengembangkan UMKM [Internet]. Retrieved Maret 2018. 2014. Available from: https://www.liputan6.com/bisnis

12. Fernandez MN. Perkuat Daya Saing, Pemasaran Produk UKM Disarankan Terpusat. 2017; Available from: https://ekonomi.bisnis.com

13. Indonesia UCFU. Penggunaan Teknologi Informasi Pada Pelaku Usaha Mikro [Internet]. Retrieved Maret 2018. 2017. Available from: http://www.feb.ui.ac.id

14. HADI ML. PENGARUH KUALITAS SUMBER DAYA MANUSIA DAN KARAKTERISTIK PERUSAHAAN TERHADAP KUALITAS LAPORAN KEUANGAN. 2015;

15. Lestari WS, Priyadi MP. Faktor - faktor Yang Mempengaruhi Kualitas Laporan Keuangan Berbasis SAK-ETAP Pada UMKM. J Ilmu dan Ris Akunt. 2017;6(10).

16. Devi, Putu Emy Susma et al. Pengaruh Tingkat Pendidikan, Pemahaman Akuntansi dan Ukuran Usaha Terhadap Kualitas Laporan Keuangan Pada UMKM (Studi Empiris pada UMKM di Kecamatan Buleleng). JIMAT (Jurnal Ilm Mhs Akuntansi) Undiksha. 2018;8(2).

17. Mulyani S. Faktor-Faktor yang Mempengaruhi Kualitas Laporan Keuangan Pada UMKM di Kabupaten Kudus. J Din Ekon Bisnis. 2014;11(2).

18. Wungow JF, Lambey L, Pontoh W. Pengaruh tingkat pendidikan, masa kerja, pelatihan dan jabatan terhadap kualitas laporan keuangan pemerintah Kabupaten Minahasa Selatan. J Ris Akunt DAN Audit GOODWILL. 2016;7(2).

19. Mahlil M, Yahya MR. Pengaruh Komitmen Kepala Daerah dan Pengetahuan 
Akuntansi terhadap Kualitas Laporan Keuangan Pemerintah Daerah di Provinsi Aceh. J Ilm Mhs Ekon Akunt. 2017;2(2):21-9.

20. Langenre SS. PENGARUH KAPASITAS SUMBER DAYA MANUSIA, PEMANFAATAN TEKNOLOGI SISTEM INFORMASI MANAJEMEN DAERAH, PENERAPAN STANDAR AKUNTANSI PEMERINTAHAN TERHADAP KUALITAS LAPORAN KEUANGAN PEMERINTAH DAERAH (Studi Pada SKPD Kabupaten Buol). 2017. 5(8).

21. Nadir R, Hasyim. Pengaruh Pemanfaatan Teknologi Informasi, Kompetisi Sumber Daya Manusia Terhadap Kualitas Laporan Keuangan Pemerintah Daerah Dengan Variabel Intervening Standar Akuntansi Pemerintahan Berbasis Akrual. J Akuntabel. 2017;14(1).

22. Chodijah S, Hidayah N. Pengaruh Pemanfaatan Teknologi Informasi dan Sistem Pengendalian Internal terhadap Kualitas Pelaporan Keuangan Pemerintah Daerah (Studi Kasus SKPD Provinsi DKI Jakarta). J Tekun. 2018;8(1).

23. Donaldson L, Davis JH. Stewardship theory or agency theory: CEO governance and shareholder returns. Aust J Manag. 1991;16(1):49-64.

24. Undang-Undang No 20 Tahun 2008 tentang Usaha Kecil dan Menengah. 2008.

25. Yadiati HW, Mubarok SEA. Kualitas Pelapor Keuangan: Kajian Teoretis Dan Empiris (Edisi Pertama). Prenada Media. 2017.

26. Undang-Undang No 20 Tahun 2003 tentang Sistem Pendidikan Nasional. 2003.

27. Undang-Undang No 11 Tahun 2008 tentang Informasi dan Transaksi Elektronik. 2008. 